\title{
INSIDENSI DAN ANALISIS FAKTOR RISIKO INFEKSI CACING TAMBANG PADA SISWA SEKOLAH DASAR DI GROBOGAN, JAWA TENGAH
}

\author{
Ryan Halleyantoro ${ }^{1}$, Anugrah Riansari ${ }^{1}$, Dian Puspita Dewi ${ }^{1}$ \\ Bagian Parasitologi, Fakultas Kedokteran Universitas Diponegoro ${ }^{1}$ \\ Corresponding email: halleyantoro@fk.undip.ac.id
}

\begin{abstract}
Helminthiasis is a non life threatening disease but causes various problems such as declining health conditions, nutrition, intelligence and productivity. Most of the helminthiasis cases in elementary students were caused by Soil Transmitted Helminth (STH), particularly hookworm. The purposes of this study were to determine the prevalence of hookworm infection and factors related to hookworm infection incidents at elementary student in Grobogan, Central Java. An observational cross sectional study was conducted using 73 stool samples from students in two elementary schools in Grobogan, Central Java. Microscopic examination was performed to determine positive stool samples containing hookworm eggs. Data about factors related to hookworm infection was obtained from a simple sanitation hygiene questionnaire. This study showed that 10 students (13.7\%) were positively infected by hookworm. School sanitation, parents with occupation related to hookworm infection risk, and student nails hygiene were identified as factors that affect hookworm infection rates in elementary school students in Grobogan, Central Java. The school needs to improve sanitation programs in the school environment and encourages health and sanitation education for students and their families.
\end{abstract}

Keywords: hookworm, elementary student, hygiene, sanitation

\begin{abstract}
Abstrak
Penyakit kecacingan merupakan penyakit akibat infeksi cacing yang cenderung tidak mematikan namun menimbulkan berbagai masalah seperti menurunnya kondisi kesehatan, gizi, kecerdasan dan produktivitas. Sebagian besar kecacingan pada siswa disebabkan oleh cacing Soil Transmitted Helminth (STH) salah satunya cacing tambang. Tujuan dari penelitian ini adalah untuk mengetahui prevalensi infeksi cacing tambang serta faktor-faktor yang dapat mempengaruhi kejadian infeksi cacing tambang pada anak usia sekolah dasar di daerah Grobogan, Jawa Tengah. Penelitian observasi dengan desain cross sectional menggunakan sampel feses dari siswa di dua SD di Grobogan, Jawa Tengah sebanyak 73 sampel feses. Pemeriksaan mikroskopis dilakukan untuk mengetahui sampel feses yang positif mengandung telur cacing tambang. Hasil menunjukkan sebanyak 10 siswa $(13,7 \%)$ positif terinfeksi cacing tambang. Data mengenai faktor resiko cacing tambang didapatkan melalui kuesioner sederhana megenai PHBS. Kebersihan sekolah, pekerjaan berisiko dari orang tua siswa serta kebersihan kuku siswa SD merupakan faktor-faktor yang dapat mempengaruhi angka infeksi cacing tambang pada siswa SD di Kabupaten Grobogan Jawa Tengah.Pihak sekolah perlu meningkatkan program sanitasi di lingkungan sekolah, menggalakkan perilaku hidup sehat serta penyuluhan kesehatan kepada siswa dan keluarganya.
\end{abstract}

Kata Kunci: cacing tambang, siswa SD, kebersihan, sanitasi 


\section{PENDAHULUAN}

Penyakit kecacingan merupakan penyakit yang diakibatkan infeksi cacing atau helminth. Penyakit ini merupakan penyakit endemik kronik dan cenderung tidak mematikan namun menimbulkan berbagai masalah seperti menurunnya kondisi kesehatan, gizi, kecerdasan dan produktivitas. Penyakit kecacingan banyak menimbulkan kerugian karena menyebabkan berkurangnya penyerapan zat gizi makronutrien seperti karbohidrat dan protein, serta menimbulkan berkurangnya jumlah darah dalam tubuh. Penderita penyakit kecacingan biasanya mempunyai gejala lemah, lesu, pucat, kurang bersemangat, berat badan menurun, batuk, kurang konsentrasi dalam belajar. Tentunya hal ini akan menurunkan kualitas sumber daya manusia karena menyebabkan gangguan tumbuh kembang serta mempengaruhi kognitif manusia. ${ }^{1}$

Penyakit kecacingan termasuk dalam 17 Neglected Tropical Disease (NTD) / penyakit tropis terabaikan. ${ }^{2}$ Penyakit kecacingan yang terjadi di Indonesia tahun 2012 adalah 22,6\% sedangan target angka kecacingan di Indonesia menurut Kementerian Kesehatan tahun 2017 adalah $<10 \%$ di setiap daerah kabupaten/ kota. ${ }^{3}$

Salah satu bentuk penyakit kecacingan adalah terinfeksi oleh cacing melalui tanah atau disebut Soil Transmitted Helminthes (STH) yang kemudian berkembang di dalam usus. Jenis cacing yang banyak menginfeksi manusia adalah cacing gelang (Ascaris lumbricoides), cacing tambang (Ancylostoma duodenale dan Necator americanus) dan cacing cambuk (Trichuris trichiura). ${ }^{1}$

Penyakit cacing usus adalah infeksi kronik yang banyak menyerang populasi balita dan anak usia sekolah dasar. Pemeriksaan tinja yang dilakukan oleh Sub Dit Diare, menyatakan jumlah kecacingan dan infeksi saluran pencernaan pada tahun 2002-2009 yang dilakukan pada 398 SD/MI di 33 propinsi memberikan hasil rata-rata prevalensi kecacingan sebesar $31,8 \%$. Beberapa survei kecacingan yang dilakukan di Pulau Jawa pada tahun 2006-2007 menunjukkan hasil yang bervariasi. Data survei kecacingan menurut Yayasan Kusuma Buana (YKB) menunjukan prevalensi kecacingan di Jakarta Timur adalah 2,5\%, sedangkan di Jakarta Utara sebesar 7,8\%. Prevalensi kecacingan di Jawa Timur pada tahun 2008-2010 adalah 7,95\% dan di Kabupaten Sleman dan DIY prevalensinya cukup tinggi yaitu 21,78\%, serta di Kabupaten Karang Asem sebanyak 51,27\%. Data pasti kejadian kecacingan di Jawa Tengah tidak ditemukan dalam profil kesehatan propinsi. ${ }^{4}$

Faktor- faktor risiko yang berpengaruh terhadap terjadinya infeksi cacing kecacingan adalah faktor karakteristik (umur, jenis kelamin, imunitas), faktor lingkungan fisik (tekstur dan kelembaban 
tanah, lahan pertanian/perkebunan, sanitasi sekolah dan rumah), faktor biologis (keberadaan cacing tambang pada kotoran hewan dan halaman rumah), faktor sosial ekonomi (pekerjaan, pendidikan, dan penghasilan), faktor perilaku (kebiasaan tidak memakai alas kaki di sekolah, di rumah dan saat bermain, kebiasaan bermain di tanah, perilaku pengobatan mandiri), faktor budaya (budaya pemeliharaan anjing/kucing, bermain tanpa alas kaki, defekasi di sembarang tempat) dan faktor lain, seperti program pemberantasan penyakit. ${ }^{5}$

Penelitian ini bertujuan untuk mengetahui faktor-faktor yang dapat mempengaruhi kejadian infeksi cacing tambang pada anak usia sekolah dasar di daerah Grobogan, Jawa Tengah. Hal ini didorong karena beberapa permasalahan di atas, seperti masih bervariasinya data prevalensi kecacingan di berbagai daerah yang diduga dipengaruhi oleh berbagai faktor risiko serta belum adanya data kecacingan terutama infeksi cacing tambang di daerah Grobogan. Penelitian ini penting sebagai langkah awal untuk pemberantasan penyakit kecacingan.

\section{METODE}

\section{Populasi dan Sampel Penelitian}

Penelitian ini dilakukan pada dua sekolah dasar di Kecamatan Brati, Kabupaten Grobogan, Jawa Tengah pada bulan Januari - Februari 2013. Desain penelitian yang digunakan potong lintang (cross sectional).

Populasi subjek dalam penelitian ini adalah murid-murid SD di Kecamatan Brati, Grobogan yang berada pada dua sekolah yaitu SD A dan SD B. Teknik pengambilan sampel menggunakan purposive sampling design, murid yang diperiksa terbatas pada kelas IV, V, dan VI. Sampel tinja yang berhasil dikumpulkan sebanyak 73 sampel.

Data mengenai faktor resiko yang diteliti didapatkan dari kuesioner sederhana tentang PHBS (Perilaku Hidup Bersih dan Sehat) yang diisi oleh responden.

\section{Prosedur dan Analisis Data}

Konfirmasi ada atau tidaknya infeksi cacing tambang adalah dengan pemeriksaan mikroskopis sampel tinja menggunakan teknik pemeriksaan tinja secara langsung dengan pewarnaan $\mathrm{NaCl}$ fisiologis. Subjek dinyatakan positif terinfeksi cacing tambang bila ditemukan telur cacing tambang dengan dinding tipis transparan pada pemeriksaan sampel feses. Data mengenai usia, asal 
sekolah, pekerjaan orang tua (ayah dan ibu) dan kelas responden diperoleh dengan cara wawancara menggunakan kuesioner. Sedangkan data kebersihan kuku, berat badan, tinggi badan, dan IMT dilakukan dengan penilaian dan pengukuran secara langsung. Variabel pekerjaan berisiko didapatkan dari data pekerjaan ayah atau ibu yang memiliki risiko terhadap kejadian kecacingan yaitu pekerjaan yang sering terpapar dengan tanah.

Data penelitian dianalisis menggunakan SPSS for Windows. Data kategorik disajikan dengan distribusi frekuensi sedangkan data numerik disajikan dengan mean (rerata). Uji bivariat menggunakan analisis chi-square atau fisher exact. Nilai kemaknaan apabila P-value $<0.05$.

\section{HASIL}

\section{Karakteristik Sampel}

Penelitian ini dilakukan di dua SD di Kecamatan Brati Kabupaten Grobogan pada siswa kelas IV, V dan VI. Jumlah responden adalah sebanyak 73 siswa. Gambaran karakteristik responden adalah seperti pada tabel 1.

Dari tabel 1 dapat diketahui bahwa rerata usia responden 11,25 $\pm 9,81$ tahun. Asal sekolah responden SD A dan SD B hampir seimbang. Jumlah responden laki-laki dan perempuan hampir sama. Sebagian besar pekerjaan ayah dan ibu responden sebagai petani. Sebanyak $71,2 \%$ orang tua responden memiliki pekerjaan yang berisiko. Sebagian besar responden duduk di bangku kelas $\mathrm{V}$ dan kelas VI. Sebanyak 62 responden $(84,9 \%)$ memliki kuku bersih. Rerata berat badan responden $30,18 \pm 9,17 \mathrm{Kg}$, sedangkan rerata tinggi badan responden $133,55 \pm 7,81 \mathrm{~cm}$. Rerata Indeks Massa Tubuh (IMT) responden adalah 16,65 $\pm 3,42$.

\section{Hasil Pemeriksaan Sampel Tinja}

Dari hasil pemeriksaan feses (Tabel 2) pada responden didapatkan hasil 13,7 persen sampel feses positif terdapat cacing tambang. Sampel dinyatakan positif bila ditemukan telur cacing tambang pada pemeriksaan feses (Gambar 1)

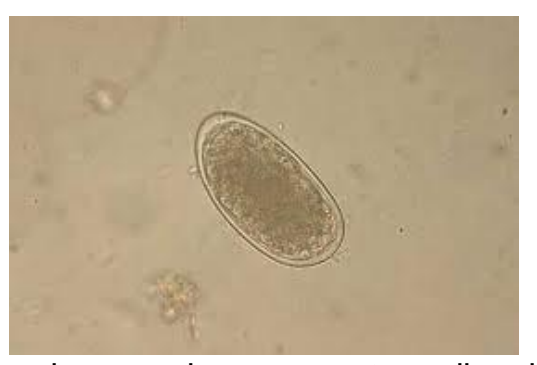

Gambar 1. Telur cacing tambang pada pengamatan mikroskopik perbesaran 40×10. 
Tabel 1. Karakteristik Responden

\begin{tabular}{|c|c|c|c|c|}
\hline No & Variabel & Jumlah & Persentase (\%) & Rerata \\
\hline 1 & Usia & & & $11,25 \pm 9,81$ \\
\hline \multirow[t]{2}{*}{2} & $\begin{array}{l}\text { Asal Sekolah } \\
\text { - SD A }\end{array}$ & 37 & 50,7 & \\
\hline & - SD B & 36 & 49,3 & \\
\hline \multirow[t]{3}{*}{3} & Jenis Kelamin & 36 & 493 & \\
\hline & - Laki-laki & 36 & 49,3 & \\
\hline & - Perempuan & 37 & 50,7 & \\
\hline \multirow[t]{7}{*}{4} & $\begin{array}{l}\text { Pekerjaan Ayah } \\
\text { - Buruh bangunan }\end{array}$ & 5 & 6,8 & \\
\hline & - Kepala desa & 1 & 1,4 & \\
\hline & - Pembuat bata & 7 & 9,6 & \\
\hline & - Petani & 38 & 52,1 & \\
\hline & - Supir & 2 & 2,7 & \\
\hline & - Swasta & 11 & 15,1 & \\
\hline & - Wiraswasta & 9 & 12,3 & \\
\hline \multirow[t]{9}{*}{5} & $\begin{array}{l}\text { Pekerjaan lbu } \\
\text { - Buruh bangunan }\end{array}$ & 2 & 2,7 & \\
\hline & - IRT & 21 & 28,8 & \\
\hline & - Pembuat bata & 7 & 9,6 & \\
\hline & - Penjahit & 1 & 1,4 & \\
\hline & - Perawat & 1 & 1,4 & \\
\hline & - Petani & 29 & 39,7 & \\
\hline & - Pembantu rumah tangga & 1 & 1,4 & \\
\hline & - Swasta & 5 & 6,8 & \\
\hline & - Wiraswasta & 6 & 8,2 & \\
\hline \multirow[t]{2}{*}{6} & $\begin{array}{l}\text { Pekerjaan berisiko } \\
\text { - Berisiko }\end{array}$ & 52 & 71,2 & \\
\hline & - Tidak berisiko & 21 & 28,8 & \\
\hline \multirow[t]{4}{*}{7} & Kelas & & & \\
\hline & - IV & 19 & 26,0 & \\
\hline & - $\mathrm{V}$ & 27 & 37,0 & \\
\hline & - $\quad \mathrm{VI}$ & 27 & 37,0 & \\
\hline \multirow[t]{3}{*}{8} & Kuku & & & \\
\hline & - Kotor & 11 & 15,1 & \\
\hline & - $\quad$ Bersih & 62 & 84,9 & \\
\hline 9 & Berat Badan & & & $30,18 \pm 9,17$ \\
\hline 10 & Tinggi badan & & & $133,55 \pm 7,81$ \\
\hline 11 & IMT (Indeks Massa Tubuh) & & & $16,65 \pm 3,42$ \\
\hline
\end{tabular}


Tabel 2. Hasil Pemeriksaan Sampel Tinja

\begin{tabular}{ccc}
\hline \multicolumn{1}{c}{ Variabel } & Jumlah & Persentase (\%) \\
\hline Hasil Pemeriksaan & 10 & 13,7 \\
$-\quad$ Positif Cacing tambang & 63 & 86,3 \\
- Negatif & & \\
\hline
\end{tabular}

\section{Analisis Faktor Risiko}

Dari analis bivariat (Tabel 3), dapat diketahui bahwa asal sekolah SD B memiliki risiko 12 kali terkena infeksi kecacingan dibandingkan dengan SD A.

Pekerjaan berisiko dari orang tua siswa memiliki kemungkinan terjadi kecacingan sebesar 1,5 kali dibandingkan dengan pekerjaan yang tidak berisiko. Kuku kotor pada responden memiliki kemungkinan terjadi kecacingan sebesar 5,333 kali dibandingkan dengan kuku bersih. Sedangkan jenis kelamin tidak berpengaruh secara statisik terhadap kejadian kecacingan.

Tabel 3. Analisis hubungan antara faktor risiko terhadap kejadian kecacingan.

\begin{tabular}{|c|c|c|c|c|c|}
\hline \multirow[t]{2}{*}{ No } & \multirow[t]{2}{*}{ Variabel } & & ingan & \multirow{2}{*}{$\begin{array}{c}\text { Rasio } \\
\text { Prevalensi } \\
\text { (PR) } \\
\end{array}$} & \multirow[t]{2}{*}{ Nilai $\mathbf{P}$} \\
\hline & & $\mathrm{Ya}$ & Tidak & & \\
\hline 1 & $\begin{array}{r}\text { Asal Sekolah } \\
-\quad \text { SD A }\end{array}$ & 1 & 36 & 12,00 & 0,007 \\
\hline 2 & $\begin{array}{c}-\quad \text { SD B } \\
\text { Jenis Kelamin }\end{array}$ & 9 & 27 & & \\
\hline & $\begin{array}{ll}\text { - } & \text { Laki-laki } \\
\text { - } & \text { Perempuan }\end{array}$ & $\begin{array}{l}4 \\
6\end{array}$ & $\begin{array}{l}32 \\
31\end{array}$ & 0,646 & 0,736 \\
\hline 3 & $\begin{aligned} & \text { Pekerjaan berisiko } \\
& \text { - } \text { Berisiko } \\
&- \text { Tidak berisiko }\end{aligned}$ & $\begin{array}{c}10 \\
0\end{array}$ & $\begin{array}{l}42 \\
21\end{array}$ & 1,5 & 0,025 \\
\hline 4 & $\begin{array}{cl}\text { Kuku } & \\
- & \text { Kotor } \\
- & \text { Bersih }\end{array}$ & $\begin{array}{l}4 \\
6\end{array}$ & $\begin{array}{c}7 \\
56\end{array}$ & 5,333 & 0,038 \\
\hline
\end{tabular}

\section{PEMBAHASAN}

Berdasarkan hasil pemeriksaan sampel tinja diperoleh 10 responden $(13,7 \%)$ positif terinfeksi cacing tambang. Hasil ini sesuai dengan prevalensi kecacingan di Indonesia yang berkisar antara 2,5\%-51,27\%. Anak usia SD merupakan usia yang rentan terinfeksi cacing. Pada penelitian Umar, prevalensi kejadian kecacingan pada anak usia SD sebesar $60 \%-80 \%$ dari semua usia responden. ${ }^{6}$ Hasil penelitian Ginting juga mengatakan bahwa prevalensi kecacingan pada kelompok umur 9-11 tahun sebanyak $60,0 \%$ dibandingkan dengan kelompok umur lain. ${ }^{7}$ 
Anak usia SD mempunyai frekuensi bermain yang cukup tinggi. Tanah pada halaman sekolah merupakan tempat yang disukai bagi siswa untuk bermain dan mungkin mengandung larva infektif cacing tambang. Kebiasaan bermain siswa yang tidak memperhatikan kebersihan diri dan lingkungan seperti bermain di tanah tanpa alas, berguling di tanah, dan tidak mencuci tangan setelah bermain dapat berpengaruh terhadap angka kejadian infeksi cacing tambang. Demikian juga kebiasaan dalam mengkonsumsi makanan yang dijual di sekolah tanpa memperhatikan sanitasinya. Siswa yang mengkonsumsi makanan di pinggir jalan memiliki prevalensi infeksi lebih tinggi daripada siswa yang tidak membeli makanan di pinggir jalan. Hal ini terjadi karena siswa seringkali tidak mencuci tangan terlebih dahulu setelah beraktivitas dan langsung makan dengan tangan yang kotor. Telur cacing yang semula berada di tanah akan dapat sampai ke makanan dengan cara diterbangkan oleh angin ataupun dengan dihinggapi lalat yang membawa telur cacing setelah hinggap di tanah/ selokan. Siswa yang yang tidak mencuci tangan sebelum makan setelah bermain di tempat yang kotor juga meningkatkan prevalensi penyakit kecacingan. ${ }^{8}$ Pada anak usia SD, cacing tambang berkontribusi dalam menyebabkan gangguan tumbuh kembang, anemia sedang hingga berat, serta berkurangnya kognitif anak.

Hasil penelitian menunjukkan prevalensi infeksi kecacingan pada SD B lebih tinggi bila dibandingkan SD A. Kondisi tersebut salah satunya dipengaruhi oleh keadaan sanitasi sekolah SD B yang kurang baik dibandingkan dengan SD A. Survei yang kami lakukan pada kedua SD tersebut didapatkan kebersihan kamar mandi jumlah jamban, dan sistem pengelolaan limbah pada SD A lebih baik dibandingkan dengan SD B. Pada SD A juga tersedia tempat cuci tangan dengan air mengalir dan sabun sehingga mengurangi risiko kecacingan pada siswa. Penelitian yang dilakukan oleh Samarang menunjukan bahwa SD yang memiliki kebersihan kamar mandi rendah berisiko terkena kecacingan. ${ }^{9}$ Hal ini juga selaras dengan hasil penelitian sebelumnya yang menyatakan bahwa tidak tersedianya jamban memperbesar peluang terjadinya infeksi cacing tambang. ${ }^{10}$ Pembuangan tinja yang benar akan mengurangi infeksi dan jumlah kecacingan sehingga pihak sekolah perlu meningkatkan sarana dan prasara yang mendukung program kebersihan dan sanitasi di lingkungan sekolah.

Salah satu penyebab infeksi kecacingan adalah cacing STH, yang merupakan kelompok parasit nematoda yang menyebabkan infeksi pada manusia melalui kontak dengan telur maupun larva cacing yang hidup di dalam tanah yang lembab dan hangat terutama pada negara-negara tropis. 
Salah satu STH yang banyak ditemukan di dunia adalah cacing tambang. Spesies cacing tambang yang sering menginfeksi manusia adalah Ancylostoma duodenale dan Necator americanus. Di dalam siklus hidupnya, cacing tambang memiliki habitat hidup dan bertelur di usus. Telur keluar bersama tinja lalu menjadi matang dalam waktu 24 jam di tanah. Telur kemudian berubah menjadi larva tingkat pertama (L1), dan berkembang manjadi larva tingkat kedua (L2) yang disebut larva rhabditiform, untuk selanjutnya berubah menjadi bentuk larva tingkat ketiga (L3). Larva ini dinamakan larva filariform yang bersifat infektif dan dapat menginfeksi manusia dengan cara menembus kulit.

Telur cacing tambang memerlukan tanah berpasir yang gembur, tercampur humus, dan terlindung sinar matahari langsung untuk hidup. ${ }^{11}$ Area pertanian adalah daerah yang relatif gembur karena diolah oleh para petani untuk dapat ditanami. Olahan tanah seperti di pertanian maupun perkebunan sangat menguntungkan bagi pertumbuhan larva cacing.

Pekerjaan orang tua yang beresiko terinfeksi kecacingan (petani, pembuat bata dan buruh bangunan) mempengaruhi kejadian infeksi kecacingan pada anak usia sekolah dasar. Hasil analisis bivariat menunjukkan pekerjaan orang tua yang berisiko memiliki kemungkinan terjadi infeksi kecacingan sebesar 1,5 kali dibandingkan dengan yang tidak. Hasil penelitian ini berbeda dengan penelitian sebelumnya yang menyatakan bahwa pekerjaan orang tua tidak mempengaruhi kejadian infeksi kecacingan. ${ }^{12}$ Perbedaan hasil tersebut kemungkinan disebabkan oleh perbedaan jenis pekerjaan utama orang tua dari responden. Pada penelitian ini pekerjaan orang tua responden yang berisiko sebanyak $71,2 \%$. Pekerjaan orang tua yang berisiko adalah yang sering terpapar dengan tanah seperti petani, pembuat bata dan buruh bangunan bila dibandingkan pekerjaan lainnya seperti penjahit, perawat, serta wiraswasta. Hal ini secara tidak langsung menjadi faktor yang dapat menyebabkan penularan kecacingan siswa sekolah dasar saat berada di rumah terutama bila orang tua tersebut tidak memperhatikan hygiene perorangan. Kebiasaan lain seperti bekerja tanpa alas kaki, tidak mencuci kaki dengan air sabun saat pulang dari bekerja, serta tidak mencuci tangan dengan bersih setelah bekerja, sebelum makan, dan setelah buang air besar dapat meningkatkan risiko penularan infeksi kepada anggota keluarga lain.

Kebersihan kuku pada penelitian ini menjadi salah satu faktor risiko yang diamati. Hasil dari penelitian ini menunjukkan bahwa kebersihan kuku berpengaruh terhadap kejadian kecacingan. Siswa yang memiliki kuku yang kotor memiliki kemungkinan resiko sebesar 5,333 dibandingkan dengan siswa dengan kuku yang bersih. Hal ini sesuai dengan penelitian sebelumnya yang menunjukkan 
kebersihan tangan mempengaruhi kejadian infeksi kecacingan. ${ }^{13}$ Ini sesuai dengan Badan Penelitian dan Pengembangan Kesehatan Depkes RI yang menyatakan keadaan tangan yang kotor akan meningkatkan prevalensi kecacingan $(21,1 \%)$ daripada keadaan tangan yang bersih $(13,8 \%) .{ }^{14}$ Namun hal ini bertentangan dengan penelitian sebelumnya yang mengatakan bahwa tidak ada hubungan yang bermakna antara kebersihan kuku dengan kejadian kecacingan pada siswa, namun penelitian tersebut juga menegaskan bahwa kondisi kuku kotor dapat berisiko 1,7 kali lebih tinggi menderita kecacingan daripada kuku bersih. ${ }^{15}$

Salah satu upaya pencegahan infeksi kecacingan adalah dengan memelihara kebersihan diri seperti kebersihan tangan dan kuku. Infeksi kecacingan kebanyakan ditularkan melalui tangan yang kotor, kuku jemari tangan yang kotor dan panjang sehingga dapat menimpan telur cacing. Badan Penelitian dan Pengembangan Kesehatan Depkes RI menyatakan bahwa siswa dengan kuku pendek, prevalensi telur cacing yang ditemukan lebih sedikit $(2,8 \%)$ daripada siswa dengan kuku panjang $(4,5 \%) .{ }^{14}$ Berdasarkan hasil tersebut faktor perilaku dari orang tua dan siswa di lingkungan rumah serta perilaku siswa di sekolah juga memegang peranan dalam terjadinya infeksi cacing tambang sehingga perlu diadakannya penyuluhan kesehatan kepada siswa dan orangtua mengenai PHBS dan pengetahuan tentang penyakit kecacingan.

Kelemahan pada penelitian ini masih terdapat faktor-faktor perilaku, lingkungan, dan pengetahuan penyakit yang tidak diamati. Faktor perilaku tersebut seperti kebiasaan cuci tangan baik sebelum makan maupun setelah buang air besar, kebiasaan penggunaan alas kaki, kebiasan buang air besar dan kebiasaan mandi. Faktor lingkungan seperti kondisi rumah, kebersihan rumah, penggunaan jamban, ketersediaan air bersih, dan lain-lain. Hal tersebut disebabkan karena peneliti tidak melakukan observasi secara langsung, serta penggunaan kuesioner memiliki bias yang cukup tinggi sehingga perlu dilakukan penelitian lebih lanjut dengan desain penelitian kohort dan menyertakan variabel perilaku, lingkungan, dan pengetahuan tentang penyakit kecacingan.

\section{KESIMPULAN}

Penelitian ini menemukan angka kecacingan pada murid kelas IV, V, VI pada dua SD di Kabupaten Grobogan adalah sebesar 13,7 \%. Kebersihan sekolah, pekerjaan berisiko dari orang tua siswa serta kebersihan kuku siswa SD merupakan faktor-faktor yang dapat mempengaruhi angka infeksi cacing tambang pada siswa SD di Kabupaten Grobogan Jawa Tengah. 


\section{REFERENSI}

1. World Health Organization. Soil transmitted helminthes Intestinal Worms. [Internet] Available from: http/www.who.int/intestinal worms/en. [diakses 9 Maret 2019].

2. Centers for Disease Control and Prevention. Which diseases are considered neglected tropical disease. [Internet] Available from https://www.cdc.gov/globalhealth/ntd/diseases/index.html. [diakses 9 Maret 2019]

3. Kemenkes RI. Peraturan menteri kesehatan Republik Indonesia no 15 Tahun 2017 tentang Penanggulangan Cacingan. Jakarta:Kemenkes RI. 2017

4. Kemenkes RI. Pedoman pengendalian kecacingan. Jakarta : Diretorat Jendral PP dan PL, Kemenkes, 2012.

5. Sumanto, Didik. Faktor risiko infeksi cacing tambang pada anak sekolah. [Tesis]. Semarang: Universitas Diponegoro;2010.

6. Umar Z. Perilaku Cuci Tangan Sebelum Makan dan Kecacingan pada Murid SD di Kabupaten Pesisir Selatan Sumatera Barat. 2005;25611.

7. Ginting A. Faktor-faktor yang berhubungan dengan kejadian kecacingan pada anak sekolah dasar di desa tertinggal Kecamatan Pangukuran Kabupaten Samosir. [Skripsi]. Medan: Universitas Sumatera Utara; 2008.

8. Mardiana, Djarismawati. Prevalensi cacing usus pada murid sekolah dasar wajib belajar pelayanan gerakan terpadu pengentasan kemiskinan daerah kumuh di wilayah DKI Jakarta, Jurnal Ekologi Kesehatan. 2008(7):769-74.

9. Samarang, Nurjana MA, Sumolang PPF. Prevalensi Soil Transmitted Helminth di 10 sekolah dasar Kecamatan Labuan Kabupaten Donggala Sulawesi. J Heal Epidemiol Commun Dis. 2016;2(2):33-8.

10. Wijaya, N.H. Beberapa faktor risiko kejadian infeksi cacing tambang pada petani pembibitan Albasia. [Tesis] Semarang: Universitas Diponegoro;2015.

11. Bisara D, Mardiana. Kasus Kecacingan Pada Murid Sekolah Dasar Di Kecamatan Mentewe, Kabupaten Tanah Bumbu Kalimantan Selatan Tahun 2010. J Ekol Kesehat. 2014;13(3 Sep):255-64.

12. Sandy S, Sumarni S, Soeyoko. Analisis Model Faktor Risiko yang Mempengaruhi Infeksi Kecacingan yang Ditularkan Melalui Tanah pada Siswa Sekolah Dasar di Distrik Arso, Kabupaten Keerom, Papua. Media Litbangkes. 2015;25(1):1-14.

13. Fitri J., Saam Z, and Hamidy M.Y. Analisis faktor faktor risiko infeksi kecacingan murid sekolah dasar di Kecamatan Angkola Timur Kabupaten Tapanuli Selatan tahun 2012. Jurnal IImu Lingkungan, 2012; 6(2).

14. Departemen Kesehatan RI. Laporan Hasil Survei Morbiditas Cacingan Tahun 2005. Jakarta: Subdit Diare dan Penyakit Pencernaan Ditjen PPM \& PLP, Depkes RI, 2006.

15. Faridan K, Marlinae L, Audhah N Al. Faktor-faktor yang Berhubungan dengan Kejadian Kecacingan pada Siswa Sekolah Dasar Negeri Cempaka 1 Kota Banjarbaru. J Buski. 2013;4(3):121-7. 